\title{
Police Reform in Thailand Post-2006
}

\author{
Krisanaphong Poothakool ${ }^{1,2}$ and Tony Glendinning ${ }^{3, *}$
}

\author{
${ }^{1}$ The President of Criminology and Criminal Justice Administration Program, Rangsit University, Thailand \\ ${ }^{2}$ Faculty of Police Sciences, Royal Thai Police Cadet Academy \\ ${ }^{3}$ Director of MRes in Social Research Program, Aberdeen University, UK, and Criminology and Criminal \\ Justice Administration Program, Rangsit University, Thailand
}

\begin{abstract}
The study analyses the operation and culture of Thai policing and the intersection between policing and politics framed by the recommendations of the Police Reform Committee (PRC), 2006-2007. The PRC's priorities were: devolving police administration, especially budgets and personnel management; increasing accountability, especially establishing an Independent Complaints' Committee; and civilianization. Those priorities were seen as clearing the ground for development of community-oriented policing longer-term. Interviews were conducted with senior members of the PRC. Afterwards non-commissioned officers' opinions were established through a countrywide survey and follow-up in-depth interviews. Their station chiefs were also interviewed. According to PRC members and serving officers' accounts the barriers to reform of police administration were political interference and nepotism, especially corruption of appointments, nominations, promotions and transfers. Local policing often involved further interference by informal networks of officials, politicians and business. The PRC's recommendations were shelved due to an unfavourable political climate. The paradox was the PRC's strategies for 'democratic' police reform were well-informed and wellfounded but its establishment had been politically motivated and it was not immune to interference by competing political factions. The study contributes to debates about moving away from authoritarian policing models in the developing world by analysing barriers to the reform of police administration in the Thai context.
\end{abstract}

Keywords: Royal Thai Police, police reform, devolved management, police accountability, community-oriented policing, police culture, political interference.

\section{INTRODUCTION}

The study examines the operation and culture of Thai policing and the intersection between policing and politics in the Thai context through an analysis of what were to be failed attempts to reform the Royal Thai Police (RTP) post-2006. Thaksin Shinawatra, former Police Lieutenant Colonel, Thai business mogul and the country's Prime Minister, had been removed by military coup d'état in September 2006. Retired General Surayud Chulanont, former Army-in-Chief and member of the King's Privy Council, was installed as the head of an interim 'civilian' government. Elections were deferred until December 2007. Surayud signed an order to establish a Police Reform Committee, 20062007 (PRC2009). The committee had a substantial budget and a period of one year to report back with its recommendations and to submit draft legislation for reform. The purpose of the present study is not only to analyse the intentions that lay behind the PRC's recommendations but also to examine the opinions of serving police officers in the RTP about the committee's priorities for reform, which were for administrative decentralization of the force and the establishment of mechanisms for police accountability. That process will allow us to understand how the RTP

*Address correspondence to this author at the School of Social Science, King's College, Old Aberdeen, Scotland, AB24 3QY, UK; E-mail: tony@abdn.ac.uk operates and its occupational and organisational culture as a key Thai institution and the reasons for its lack of reform. The Chair of the PRCwas retired Police General Vasit Dejkunjorn, former Chief of the Royal Court Police (Suriyasarn and Moore 2006).

\section{The Wider Thai Context}

Thailand is a developing country designated as 'upper middle income' (World Bank 2012). Its total economic output in terms of gross domestic product (GDP) may well place it in the top 20 per cent of countries globally but in terms of per capita gross national income (GNI) it ranks in the bottom half only (World Bank 2011). Thailand is cast asan economic 'success story' but it has much remaining poverty and stark income, education and health disparities and an on-going state of emergency in its Southern provinces (McCargo 2006). In addition, Thailand has endemic corruption problems bound up with a culture of informal networks of power which operate through patronage (Ockey 1998) and involve the abuse of formal power [itthiphon] by the application of informal influence [amnat] (Tamada 1991) made worse by the presence of godfathers [jao pho] (McVey 2000) and election vote-buying in the country's rural provinces (Callahan 2005). Transparency International's 2011 corruption perceptions index $(\mathrm{CPI})$ ranked the country down at eightieth position (Roberts and Provost 2011). 
To locate the RTP among the country's other institutions at the time the police reform committee was established, analysis of World Values Survey data (WVS-Thailand 2007) indicate that some seventy per cent of Thais had confidence in their justice system. A similar proportion expressed confidence in the traditional Buddhist temple (McCargo2004). However, citizens appeared split over the country's powerful military (Chaloemtiarana 2007). Fifty-one per centreported confidence in the Armed Forces immediately following the 2006 coup d'état. Citizens were also split over the country's factional media (McCargo 2000). WVS survey results also indicate that only a minority of the public had confidence in the Civil Service in general (44 per cent) and the Royal Thai Police in particular (43 per cent). There was less confidence still in Parliament (33 per cent) and fewer than one-in-four of the Thai WVS participants had confidence in the country's political parties (23 per cent). Many also mistrusted big business in Thailand (25 per cent). Corruption as a growing 'political issue' since the late 1980s is a major reason for the populace's lack of confidence in Thai bureaucracy, civil servants, government and business interests, including corruption of the RTP (Phongpaichit and Piriyarangsan 1996: 1 ; 108). The WVS-Thailand survey did not ask about the country's other key institution, the monarchy and King (McCargo 2005).

\section{The Modern History of the Royal Thai Police}

The modern force came to the fore in the 1950s under Police General Phao Sriyanon ${ }^{1}$ when it was funded, equipped and trained with support from the United States, strategically to counter the perceived threat of communism in Southeast Asia (Fineman1997). The police became powerful along with the Thai military. The end game in a struggle between competing factions within the 'armed forces' saw Phao allowed to go into exile in 1957, having

\footnotetext{
${ }^{1}$ Foreigner Captain Ames was brought in to set up a police brigade to operate alongside the traditional Siamese patrol brigade in Bangkok in the mid nineteenth century. From 1875 the new brigade operated under regulations, duties and ordinances for policing the city. Jardine followed from British India. Lawson then amalgamated and modernized the police and patrol brigades to form a municipal constabulary on the British model at the beginning of the 1900s. A separate provincial brigade was built up along military lines for Siam's internal and border security. The two were brought together as a single department in 1915. October 13 became 'Police Day'. The value of the police to maintain political power became apparent during the 1932 revolution to establish constitutional monarchy. Its role in military totalitarian government emerged during Field Marshal LuangPhibunsongkhram's first period as Prime Minister, 1938-44, especially the Santibarn (Special Branch). Police General PhaoSriyanon's extra-legal operations during the post-war period, 1948-57, were prosecuted by an inner-circle of officers, the 'Knights of the Diamond Ring'. Phao's (prophetic) motto for the modern force was, 'There is nothing under the sun the Thai police cannot do.' (Phongpaichit and Baker 2004: 153).
}

amassed a personal fortune. The faction led by Field Marshal Sarit Thanarat wrested control in a military coup d'état. Sarit became Prime Minister in another coup d'état in 1958, and eventually, he acted as Chief of Police as well. His period of leadership has been characterized as 'despotic paternalism' (Chaloemtiarana 2007) and his authoritarian legacy continued after his death.

A decade later student protests against military rule were met with police brutality and killing of demonstrators in 1973 and 1976 (Baker and Phongpaichit 2009). The RTP's involvement was review edonly later in 1979 but readjustments and modifications of the force did not include any major reorganization (PRC 2009:4). Indeed, after a decade of economic development under Premocrarcy in the 1980s (Laothamas 1992) another coup d'état led to a new wave of mass protests in Bangkok in 1992 (Baker and Phongpaichit 2009). There were further deaths and outrage over the RTP's response. Pressure mounted for more open and participatory forms of governance as a whole, leading to Thailand's 1997 Constitution (Connors 1999). Under that 'democratic' reform: legislation for a National Police Board aimed to provide more representation through elected officials; the RTP was moved away from the bureaucratic Ministry of Home Affairs and made responsible to the elected Prime Minister's Office; the position of Parliamentary Ombudsman was set up to receive complaints about the Civil Service, including officers of the RTP; and; Regional Police Boards were established to prompt public involvement.

\section{According to the PRC's Chair:}

'The Royal Thai Police is an inherited product of the country's aged-old feudalist governing system. It is strongly centralized, with a powerful Commissioner-General at the top, reporting directly to the Prime Minister. Originally connected with the Royal Thai Army, the RTP is vaguely regarded as "the fourth branch of the armed forces."'

(PRC 2009:i)

\section{Establishment of the Police Reform Committee}

General elections saw Thaksin Shinawatra assume power in 2001 (McCargo and Pathmanand 2005). He was from Chiang Mai in the North originally and he was 
the first Prime Minster to come from the ranks of the police. He had built a business empire which survived the economic collapse of 1997 (Phongpaichit and Baker 2004). In government, under Thaksinomics, his efficiency drive to introduce modern management principles to the Civil Service seemed to have little consequence for the RTP. The Police Law of 2004 did require local boards to be set up at police station level throughout the country, to promote community involvement, but in practice, such boards supported the operation of informal networks among local police, officials, politicians and business, rather than represent wider community interests. Thaksin was re-elected in the general elections of 2005 only to be removed in the coup d'état of 2006. His removal was described as a 'good coup' by the Thai establishment (Connors and Hewison 2008). His political opponents despised his methods and populist brand of politics. They complained about autocratic leadership and especially misuse and misdirection of the RTP as a political tool. They pointed to the prosecution of his 'War on Drugs' policy (Phongpaichit and Baker 2004:253-67). Thaksin went into exile abroad to avoid charges of tax evasion and corruption in 2007. As the PRC's Chair put it: 'the police are constantly criticized for negligence, bias, abusage of power and brutality' (PRC 2009:ii).

\section{The Police Reform Committee's Claims to Legitimacy}

From the viewpoint of the Thai establishment, the PRC was able to claim legitimacy on a number of grounds: first, the self-evident need to check the rampant abuse of police power for political ends; second, pressure on the upper echelons of the RTP to agree to reform; third, widespread mistrust, lack of confidence and unpopularity of the police; fourth, the public status of retried Police General Vasit Dejkunjornas the committee's Chair $^{2}$ as a well-known figure with years of distinguished service in the force, separate from RTP Headquarters; fifth, the makeup and expertise of Vasit's committee, allied to a national consultation process; and finally; the committee's professionalism in justifying its recommendations by reference to aspects of modern, international police administration which could be adapted to fit the Thai context. The PRC's report stated that the aim of

\footnotetext{
${ }^{2}$ Vasit was a commentator for Matichon publishing group and well known as the author of a series of detective novels about Thai police operations. His novels' heroes were police inspectors who fought crime, godfathers, politicians and corruption hindered by their bosses and the administration ('Special Branch' 1996; 'Chief Inspector' 1994; 'Savage Inspector' 1987).
}

government policy was to develop a police organization which was 'transparent, accountable, responsible and modernized ... integrated within the whole justice process ... [which] with decentralization ... will be able to serve the people more efficiently, equally and fairly, and will be more credible and trusted ...' (PRC 2009:3-5). Vasit had served as Chief of the Royal Court Police for some years and he wrote a popular memoir in his retirement called 'In His Majesty's Footsteps' (Suriyasarn and Moore 2006). Vasit explained how the King had become a role model for his own actions. He commended Thais, especially government officials and public servants, to be guided by the principle of selfless service to their country. That located Vasit within a particular 'political' camp (McCargo 2005).

\section{The Police Reform Committee's Recommendations}

The PRC set up five sub-committees, responsible for: (1) restructuring police administration; (2) reviewing human resource and professional development; (3) examining the police's place within the criminal justice system as a whole; (4) public relations and consultation during the committee's reporting process; and (5) to provide academic support and draft legislation to implement the committee's recommendations (PRC 2009: 10-11). The PRC's 'wish list' for the reform of a closed, authoritarian and hierarchical institution that employed traditional policing methods was to:

I. Decentralize the RTP to metropolitan, provincial and other police bureaus, including devolved budgets, personnel administration, transfers and promotions;

II. Create public participation in police administration through PPCs (Police Policy Committees);

III. Monitor police performance and relations with the public through an ICC (Independent Committee of Complaints);

IV. Transfer a range of non-police functions to other state agencies;

V. Develop the investigations' system through a central investigative directorate;

VI. Reorganize operations at the station level towards more autonomous, problem-focused, community-oriented policing and more representative local boards; 
VII. Develop police recruitment, education and training;

VIII. Review police salaries and welfare as separate within the Civil Service;

IX. Eliminate military ranks for non-commissioned officers (NCOs) and develop career progression in its place, related to civilianization of the force, and;

X. Establish an office for justice system reform generally.

The PRC's final reportlaidout a two-stage process along with implementation strategies. Reform would start with an Office for Police Reform (OPR) run separately from the existing National Police Agency and reporting independently to a changed National Police Commission (PRC 2009: 34). The OPR was only the first step towards the PRC's long-term goal, which was its tenth and final recommendation, to enact 'joined up' justice system reform (PRC 2009: 30).

The PRC saw its first three recommendations as its key priorities at stage-one of the reform process: decentralizing the current administration to Police Bureaus; opening up the administration through requiring Police Bureaus work with Police Policy Committees (PPCs); and making the administration accountable through the operation of an Independent Committee of Complaints (ICC). The PRC wanted to decentralize police administration to regional, metropolitan and other bureau levels, especially devolved police budgets and devolved personnel administration of the RTP's current system of appointments, nominations, transfers and promotions (ANT\&P). Reformed PPCs would be responsible for formulating policy for their respective devolved organizations. The thinking was: ' $\ldots$ with appropriate and efficient management, the PPCs will become a shield against political interference while insuring accountability' (PRC 2009:22). It is notable that the PRC drafted legislation quite separately for its new ICC to act as an independent oversight mechanism. In practical terms, the PRC was also concerned about the scale of interference in the day-to-day work of investigating officers at the station level, detectives and interrogators, under existing practices and police culture and they recommended setting up a central investigative directorate too (PRC 2009: 25). Investigating officers were used to employing quasilegal methods ignorant of the law and citizens' rights.
They were poorly trained and over worked on relatively low salaries, and so, open to outside influence, and to interference from their station chiefs, and their chiefs' bosses, who had the 'final say' on the prosecution of cases.

The PRC's fourth through eighth recommendations - focusing on everyday operations and ways of working, recruitment and training, resources and work conditions - were presented as stage-two of the reform process in a move towards 'community-oriented' policing. The priorities set out as stage-one were deemed essential because they were pre-requisites to the development of policing using modern methods to international standards at stage-two. Of course, those same priorities would also serve to disable the RTP as a factor in Thai politics. The PRC provided justifications for its own reform program by reference to experiences and models of policing elsewhere as required. Its recommendations were framed by community-oriented reform programs involving 'decentralization of command', 'increased accountability towards the public' and 'civilianization'of the RTP where chief among the internal impediments to reform were existing police culture and norms 'grounded in traditional notions of the police role' and the 'bureaucratic isolation' of reform programs within the administrative hierarchy, as identified by Skolnick and Bayley (1988). Practical implications of the PRC's proposals would be worked out as the second stage of reform. $^{3}$

\section{METHODS}

The study used both qualitative and quantitative methods. A large-scale questionnaire survey was combined with in-depth interviews of serving officers. Permission for the study was granted only after a formal presentation at RTP Headquarters in late- $2008^{4}$. Contact was then made with the Police Chief's Office of the Metropolitan Bureau (Capital-Bangkok), Provincial Police Region 8 (Upper North-Chang Mai) and Provincial Police Region 5 (Upper South-Surat Thani) to gain access to police stations. Police stations were selected at random in advance from among 'large' and

\footnotetext{
${ }^{3}$ Different members of the PRC were advocates of particular models of police administration, such as community aspects of the Japanese policing model (Kittiyaluck2007), but without necessarily acknowledging fully the challenges facing such models. Their purpose was to lend authority to the recommendations for reform.

${ }^{4}$ At that time the Prime Minister's nomination of a new National Police Chief had been blocked by the National Police Board, due to manoeuvring among political factions. The Acting Commissioner-General had no absolute authority in law to oversee administration of the RTP.
} 
Table 1a: Questionnaire Survey of Non-Commissioned Police Officers, RTP 2009

\begin{tabular}{|c|c|c|c|c|c|c|c|}
\hline \multirow{3}{*}{$\mathbf{n}=$} & \multicolumn{2}{|c|}{ Bangkok } & \multirow{2}{*}{\multicolumn{2}{|c|}{$\begin{array}{c}\text { Chiang Mai } \\
\text { Province }\end{array}$}} & \multirow{2}{*}{\multicolumn{2}{|c|}{$\begin{array}{c}\text { Surat Thani } \\
\text { Province }\end{array}$}} & \multirow{3}{*}{ Total $^{*}$} \\
\hline & \multirow{2}{*}{ Central Large } & \multirow{2}{*}{ Metro' Medium } & & & & & \\
\hline & & & Medium & Small & Medium & Small & \\
\hline Distributed & 150 & 75 & 150 & 75 & 150 & 75 & 675 \\
\hline Returned & 146 & 73 & 133 & 72 & 130 & 69 & 623 \\
\hline
\end{tabular}

Table 1b: National and Survey Sample Distributions Across Police Sections, RTP 2009

\begin{tabular}{|c|c|c|c|c|}
\hline Police sections & National & NCO Sample & Per cent difference & Sample $n=$ \\
\hline Traffic & $10 \%$ & $10 \%$ & $0 \%$ & 60 \\
\hline Crime Suppression & $30 \%$ & $33 \%$ & $+3 \%$ & 211 \\
\hline Crime Investigation & $15 \%$ & $7 \%$ & $-8 \% *$ & 43 \\
\hline Case Interrogation & $20 \%$ & $19 \%$ & $-1 \%$ & 118 \\
\hline General Affairs & $20 \%$ & $28 \%$ & $+8 \% *$ & 173 \\
\hline Others & $5 \%$ & $3 \%$ & $-2 \%$ & 18 \\
\hline Total & $100 \%$ & $100 \%$ & & 623 \\
\hline
\end{tabular}

Notes:

*Statistically significant differences from national distribution, Chi-sq.(5) $=55.13, p<0.01$.

'small' stations in each region. ${ }^{5}$ Station chiefs were contacted by their bosses. The interviews and survey got underway in mid-2009 and lasted for six months. Fieldwork was undertaken by an RTP officer on research leave. Original preparations for the study had involved a series of visits by the RTP officer and his UK collaborator throughout 2008 to spend time with the officer's former classmates from the National Police Academy some ten years after graduation, or with contacts introduced by those classmates. Visits were made to classmates and contacts posted to roles and sections across the country. ${ }^{6}$ Conversations took place during down time in restaurants, pubs and clubs away from operations and involved catching up on police news and careers and explaining to the UK outsider about Thai society and policing. Preparatory ethnographic work was done to understand the situation on the ground prior to undertaking the full study. In addition, an expert adviser to the PRC provided an introduction to a senior bureaucrat of the Justice Department who had worked on the PRC, and by snowballing, led to senior members of the PRC, and

${ }^{5}$ The station in central Bangkok had more than 300 officers; the metropolitan and 'medium' provincial stations had between 100 and 300; the 'small' stations had less than 100

${ }^{6}$ Classmates and contacts were not posted to police stations selected at random for the full study. ultimately, to its Chair. Interview and survey materials for the full study with serving police officers were first piloted by the research team in early-2009.

Brewer (1993) observed that it is often necessary when researching the police to tackle the negative effects of sensitivity and reactivity by making pragmatic compromises which depart from textbook practice during his study of routine policing at the time of 'the Troubles' in Northern Ireland. The present study also had to compromise on what RTP managers and station chiefs required and because it combines different data collection methods with different groups of informants it also had to address the challenge of triangulating results. According to Brewer and Hunter (2006: 4), the fundamental strategy for triangulation is to attack a research problem with an arsenal of methods that have non-overlapping weaknesses in addition to their complementary strengths. The make-up of the survey sample of non-commissioned police officers (NCOs) may have been compromised by hierarchical selection and co-optation of participants by their superiors, for example, but NCOs' responses to the self-completion questionnaire and their accounts from the face-to-face interviews can be compared with each other, and also with the interview accounts of their station chiefs. As it transpired, sample distributions and general 
Table 2: Interviews with Officers and Reform Committee Members, RTP 2009-2010

\begin{tabular}{|c|c|c|c|c|c|c|c|}
\hline \multirow[t]{3}{*}{$\mathbf{n}=$} & \multicolumn{2}{|c|}{ Bangkok } & \multirow{2}{*}{\multicolumn{2}{|c|}{$\begin{array}{c}\text { Chiang Mai } \\
\text { Province }\end{array}$}} & \multirow{2}{*}{\multicolumn{2}{|c|}{$\begin{array}{c}\text { Surat Thani } \\
\text { Province }\end{array}$}} & \multirow{3}{*}{ Total } \\
\hline & \multirow{2}{*}{$\begin{array}{l}\text { Central } \\
\text { Large }\end{array}$} & \multirow{2}{*}{$\begin{array}{c}\text { Metro' } \\
\text { Medium }\end{array}$} & & & & & \\
\hline & & & Medium & Small & Medium & Small & \\
\hline a. Station Chiefs: & $1^{\$}$ & 1 & 1 & 1 & $1^{\wedge}$ & 1 & 6 \\
\hline b. Non-commissioned officers: & 3 & 5 & 4 & 5 & 4 & 5 & 26 \\
\hline (Traffic & 1 & 1 & $1^{*}$ & 1 & 1 & 1 & 6) \\
\hline (Crime Suppression & 0 & 1 & 0 & 1 & 0 & 1 & 3) \\
\hline (Crime Investigation & 0 & 1 & $1^{*}$ & 1 & $1^{*}$ & 1 & 5) \\
\hline (Case Interrogation & $1^{*}$ & 1 & 1 & 1 & 1 & 1 & 6) \\
\hline (General affairs & $1^{*}$ & 1 & 1 & 1 & 1 & 1 & 6) \\
\hline c. Committee: & the chair, 2 sub & chairs, se & ivil servant & 2 exper & isers to th & nmittee & 6 \\
\hline
\end{tabular}

Notes:

*Interviews conducted in the presence of a senior officer.

${ }^{\$}$ Neither tape-recording nor note-taking allowed; ${ }^{\wedge}$ No tape-recording allowed.

representativeness appeared sound and NCOs seemed willing to participate.

Table 1a shows the survey sample quotas and numbers of completed questionnaires. Station chiefs chose to delegate responsibility to promoted officers to pick participants in the station's various sections. ${ }^{7}$ NCOs might opt out due to lack of interest, lack of time or to avoid trouble. Chiefs assured confidentiality. The response rate was over 90 per cent ( $n=623$ out of 675 ) even when spoiled returns were counted. Concluding written comments were made by one third of the survey participants. Table 1b compares the make-up of the survey sample with national figures. There was overrepresentation of the 'general affairs' section and under-representation of the 'crime investigation' section but good matches for the' traffic', 'crime suppression' and 'case interrogation' sections. The modal age of participants was $40-44$ years with $21-25$ years of service. The majority were high school graduates at most. Two-thirds held the top NCO rank of Senior Sergeant Major. One-quarter were women officers. Women NCOs worked desk jobs in administration or as PAs to senior officers. ${ }^{8}$

Table 2 provides a breakdown of in-depth interviews conducted for the study. The interviews with serving

\footnotetext{
${ }^{7}$ The investigation section comprises case-detectives in the field and interrogation section case-investigators in the office. The suppression section is responsible for serious crime, such as relating to mafia, drugs and murders, supervised centrally and operating across stations.

${ }^{8}$ Women were admitted as recruits to the elite officer class of the Police Cadet Academy for the first time in 2009. Historically, the Pre-Cadet Academy combined prospective cadets with ambitions to join the upper echelons of the Army, Navy, Air Force and Police to instil a military ethos.
}

officers were done separately from the survey, and where officers were willing, recorded for transcription. The aim was to interview one NCO from each the sections of operation in each of the randomly selected police stations, and the station chief. It proved hard to arrange interviews with crime suppression officers in larger stations. In central Bangkok, for example, repeated visits were required because even desk sergeants were involved in the 'mob control' of political demonstrations in the capital. ${ }^{9}$ Twenty-one out of the target total of thirty NCOs were interviewed in a separate room and five more NCOs were interviewed while in the presence of a senior officer. The six station chiefs were interviewed afterwards in their own office. Two chiefs refused to be recorded and one of those would not allow note-taking. Opinions were treated as confidential and managers were not given access to data. In addition, the Chair, two senior members, a senior bureaucrat and two experts from the PRC were interviewed.

\section{FINDINGS}

\section{Non-Commissioned Officers' Responses to the Questionnaire Survey}

The self-completion questionnaire began by asking NCOs about choosing a career in the police from

\footnotetext{
${ }^{9}$ Mass demonstrations and occupations by the anti-Thaksin PAD (People's Alliance for Democracy) Yellow Shirts returned to Bangkok in 2008 after the results of the new general elections returned a pro-Thaksin government, even after his removal and exile abroad. Opposition Red Shirts staged mass protests thereafter when leaders of that new pro-Thaksin elected government were also required to stand down by the Constitutional Court. Political turmoil continued.
} 
Table 3: NCOs' Opinions of Police Management and Administration, RTP 2010 ( $N=623$ )

\begin{tabular}{|l|c|}
\hline Police management and administration: & Agreement \\
\hline \hline $\begin{array}{l}\text { a. National policy usually has been formed on the basis of what Provincial Police Regions 1 to } 9 \text { and the Metropolitan } \\
\text { Bureau agree. }\end{array}$ & $82 \%$ \\
\hline b. Regional Police Chiefs have absolute power in terms of police management and operations. & $82 \%$ \\
\hline c. The current ranks structure is suitable for police management and should not be changed. & $62 \%$ \\
\hline d. Only the minority of superiors put pressure on rank-and-file officers in respect of their police jobs. & $61 \%$ \\
\hline \begin{tabular}{l} 
e. In general, police officers have been appointed and transferred based on effectiveness for individual police jobs. \\
\hline f. Both influential persons and politicians have strongly affect police administration
\end{tabular} & $53 \%$ \\
\hline
\end{tabular}

among a list of reasons. The majority answered pragmatically, 'job security' (62 per cent of NCOs). The sample was split on the notion of 'public service' (only 48 per cent agreed that reasons included 'a desire to serve the community') and the majority saw police work neither as 'varied and challenging' (60 per cent) nor as offering 'opportunities for career advancement' (70 per cent). NCOs' responses gave a picture of a rank-andfile career as routine work in a fixed role without variety, challenges or progression but with job security on moderate incomes and benefits. The majority saw they had joined an organization with an ethos of following orders in the chain of command without question or initiative where they were accountable to their superiors only. Opinions emphasize an authoritarian approach with traditional methods of patrol and arrest rather than delegating command, engaging with the public, taking initiative or carrying out problem-oriented policing.

Non-commissioned officers' preferred option among different answers to another (two-part) question about the reasons why 'policing is becoming harder and the crime rate increasing' and various strategies by which 'policing could be more effective, crime controlled and law enforced' also emphasized an authoritarian approach employing traditional methods. The majority chose the explanation 'on their own, police officers cannot enforce the law and maintain stability and order' (65 per cent) but combined with a strategy of giving the police 'more authority and powers' (63 per cent) to fight crime. That is the public should support them, for instance as their informants, and allow them the power and authority to get the job done. Indeed, the majority opinion of NCOs was not compatible with decentralization of command, accountability to the public and civilianization of ways of working and interactions in everyday policing. The PRC had envisaged the use of more community-oriented policing methods happening at the second-stage of reform after the resolution of deep-seated institutional problems with the RTP's administration.
The PRC believed reform would need to be topdown with the devolution of power and authority making senior officers responsible at regional, metropolitan and other bureau level. Noncommissioned officers believed power and authority concerning policies and operations were devolved already (Table $\mathbf{3 a}$ and $\mathbf{3 b}, \mathbf{8 2}$ per cent) and the majority saw military rank structures and relationships with superiors as suited to the RTP as it was constituted (Table 3c and 3d, 62 and 61 per cent, respectively). They were divided on the RTP's personnel administration, and particularly the system of annual police movements (ANP\&T). One-half of the NCO survey sample saw the current system as an effective way of doing things, given the alternatives, and as an integral to police culture (Table $3 e, 53$ per cent). NCOs were unambiguous about the effect people of influence [amnat] and politicians had on the RTP's administration (Table 3f, 80 per cent agreed outside interference was the norm).

The PRC saw establishing an ICC and PPCs as priorities in making Bureau managers accountable within a devolved administration, alongside a reformed National Police Commission. Non-commissioned officers certainly agreed that public confidence and trust would improve if the RTP's practices were made more transparent (Table 4a, 87 per cent). Nonetheless, the majority regarded the existing internal audit system for monitoring police misconduct as 'sufficient' and 'effective and efficient' (Table 4b and 4c, 63 and 60 per cent respectively) despite a similar proportion of NCOs also agreeing that 'too often, the criminal activities of officers, such as drink driving, theft, drug possession and bribery go unpunished' (Table $\mathbf{4 d}, 68$ per cent). ${ }^{10}$ They were clear about the quasi-legal and resultsdriven methods used by the RTP, and condoned by

\footnotetext{
${ }^{10}$ The great majority also agreed that under the internal audit system the treatment of officers was not equal when it came to investigating and disciplining cases of misconduct.
} 
Table 4: NCOs' Opinions About Police Transparency and Conduct, RTP 2010 (N = 623)

\begin{tabular}{|c|c|}
\hline Police transparency and misconduct: & Agreement \\
\hline a. The transparency of police practices need to be improved to develop greater trust and confidence from the community. & $87 \%$ \\
\hline c. The internal audit system is effective and efficient enough to supervise police activities. & $60 \%$ \\
\hline $\begin{array}{l}\text { d. Too often, police managers are not able to punish criminal activity of officers (for example, drink driving, theft, drug } \\
\text { possession, bribery). }\end{array}$ & $68 \%$ \\
\hline f. Senior police administrators are only interested in the number of arrests and convictions, not in how results are achieved. & $78 \%$ \\
\hline
\end{tabular}

their superiors. Rather than 'respecting civil rights,' ends justified the means 'when catching criminals' (Table $\mathbf{4 e}$ and $\mathbf{4 f}, 78$ and 73 per cent respectively). Non-commissioned officers' opinions about priority recommendations for transparency were ambiguous. They saw positives but understood that such mechanisms would run counter to established practices. The current internal audit system suited police culture and the workings of an organization run along quasi-military lines.

Non-commissioned officers' pragmatic opinions about the RTP's closed and hierarchical administrative system can be set against their belief that more contact with the general public would be a good thing (93 per cent). Indeed, the great majority of NCOs wanted to see improvements both in transparency and public confidence (91 per cent). Seeming contradictions in responses to different survey questions reflected NCOs recognition of how the RTP operated in reality, with its own internal logic and purposes. Meaning most NCOs also agreed that senior managers should be made accountable to the law rather than the Prime Minister's Office (90 per cent) and that senior managers should not play the major role in any reorganization of RTP administration (72 per cent). Civilianization of the RTP was also seen as a necessary precursor to the reform of policing methods (71 per cent). Nonetheless, forty per cent of NCOs still did not agree that the RTP's 'top operational priority should be to serve the needs of individual citizens and local communities' and more than seventy-five per cent remained sceptical about the PRC's strategy of 'formal reorganisation and restructuring on a national basis' as initiating changes in policing locally.

\section{Non-Commissioned Officers' Responses to a Concluding Open-Ended Question}

One-third of NCOs were expressly critical of current police administration and chose to write further comments in the final open-ended section of the selfcompletion questionnaire. Comments were revealing of drivers behind RTP administration and lack of accountability. Non-commissioned officers wrote that senior officers favoured their 'own' and that managers were not accountable for decisions in ANP\&T and procedures were opaque and uncertain. It was suggested a 'spoil system' [patronage system] ${ }^{11}$ operated to benefit senior officers, often involving considerable sums of money. They felt frustrated, bypassed with little opportunity for movement to better or different positions based on performance and merit. They wrote that the rank-and-file were not encouraged to serve the public, and instead, they focused their energies on working for senior officers, acting as their 'followers' in anticipation of returns. One NCO wrote: 'Police administration is poor. Duties are decided based solely on the relationships you have.'

Non-commissioned officers wrote that too oftenfrom Police Generals to Constables, especially senior officers who were best placed to abuse their status officers took 'full advantage' of a police career for personal gain, disregarding their duty to the public. One NCO wrote: 'Officers should have moral principles, not just focus on the "advantageous" aspects of their jobs.' They reported interference in operations and investigations without apparent justification. Some superiors were even said to embezzle the 'advantages' of those under their command, including NCOs' special allowances earmarked for 'mob' control of demonstrators or for 'special' operations such as those involving narcotics. They complained that their superiors criticized them arbitrarily, not only about

\footnotetext{
${ }^{11} \mathrm{~A}$ spoil system is one where after work to secure a position of power and authority a faction provides jobs as reward for the support of its followers and as incentive for future support of the faction, originating from corrupt political practices in the United States.
} 
professional matters. In all of this, they wrote the rankand-file had no effective means of protection against such abuses. They wrote that: resources for operations, such as weapons and equipment, were limited, old and unreliable; training was inadequate, outmoded and incompetent, and; workloads in key areas were unsustainable without enough staff to complete the section's duties.

Non-commissioned officers also wrote that police bureaucracy was a major obstacle to their operations locally. Often they had to gain permission before acting and senior officers might check with headquarters also. The chain of command was slow, inflexible and unresponsive, deterring and undermining local initiative. Are current the me was that police administration was subject to interference by 'influential' people and politicians, locally and nationally. ${ }^{12}$

\section{Interview Accounts of Non-Commissioned Officers, Station Chiefs and Committee Members}

It was difficult to engage the majority of NCOs with alternative notions of more open and participatory policing during the interviews. Non-commissioned officers are not expected to have opinions about such matters. The basis for their accounts was established local practice and organizational culture. On the other hand, station chiefs were familiar with thinking behind community-oriented methods- delegating decisionmaking, changed emphasis in patrols, working on public relations and involvement, developing crimeprevention programmes and so on- but only two of the six station chiefs actually believed in such approaches: one chief in metropolitan Bangkok and another chief in the rural South. As was found with the survey results, and echoing the opinions of their station chiefs, only a minority of NCOs were critical of current RTP administration and strongly supported change in faceto-face interviews. For example, rank-and-file interviewees often claimed the RTP had been decentralized under previous police legislation (2004 and 1997). A Police Inspector in Crime Suppression interrupted one of his NCOs during an interview to say:

Senior police managers and the authorities claim that it is decentralized. In

\footnotetext{
${ }^{12}$ The example was given of failure to appoint a new Commissioner-General at the national level.
}

practice, senior police managers at Police Headquarters and politicians at both local and national level intervene in police management in respect of police transfers and nominations. Most police officers realize this but no one complains or disputes it. All of us have discipline and must follow orders.

(Inspector, Suppression, large station, Upper North)

As to the decentralization of personnel administration, according to a Station Chief from the South, the operation of the RTP's system of annual movements (ANP\&T) remained at the control of RTP Headquarters and was subject to institutionalized practices of manipulation and interference:

...the spoil system [patronage system] remains in the force; therefore, promotion is not based on police morality and ability... Senior police managers at $\mathrm{HQ}$, Provincial Police Regions and politicians regularly reach agreements about transfers so as to put their own officers into the desired positions. The connections which a police officer has are the top priority, rather than the officer's ability ... It may appear this [decentralization] has been regulated by police law [2004], but police law, in practice, is not the main consideration when it comes to police transfer and nominations...I agree that the Chief of each Provincial Police Region should have the final say in moving officers in their own regions ... In practice the Chiefs of Provincial Police Regions just listen to what their bosses command and then just do it.

(Chief of smallstation, Upper South)

Current personnel administration was centralized and driven by informal networks of power and influence. The organization's annual round police movements was manipulated to consolidate power. Factions within the force competed for dominance.

As to the PRC's recommendation for greater public involvement through establishing PPCs at the bureau level, followed by the development of more communityoriented policing and committees at the station level, 
one Station Chief in the North felt local people did not understand what was meant by 'public participation':

The notion of community engagement now is enacted by Police Law [2004]. Due to this law, a local police board has been set up at every police station. Members are from various agencies, as local representatives, such as Colleges or District Offices, but they know nothing about policing. In practice, members who attend relay to me various petty problems... actual policing and serious matters are not brought up. Some members have never attended a meeting, even elected officials like attorneys who know the justice system. Often members do not feel any responsibility to act as the public's representatives.

\section{(Chief of large station, Upper North)}

A former senior officer was damning about the makeup of current police boards:

Station chiefs often choose members from among the middle and upper class of society as these are the groups able to fund policing. We have to realize that funding is low and station chiefs face budget deficits. It is essential for the police locally to have social connections able to support their operations...

The major problem of local boards now is the recruitment procedure is left to what the station chief decides. Personal relationships are a fundamental aspect of membership. Influential people or local politicians wish to partake in local boards for their own benefits. Resources and equipment are provided and contributions made when requested. In turn, the police turn a blind eye when some board members break the law...

Influential people, businessmen and others, serve on the Regional Police Boards in order to maintain a close relationship with the police. These 'representatives' in the guise of legitimate community spokespersons say they are satisfied with regional arrangements and with local policing. They do this to serve their own interests. It has been widely said that board members act like ATM machines for the police.

(Senior member of PRC)

A bureaucrat who had been assigned to work with the PRC offered arguments which are often used to explain the need to retain centralized administrative control in the Thai context. The country was not ready to operate more open and participatory structures. Chaos would ensue due to lack of public understanding and rampant self-interest. Structures would be even more subject to abuse than the current administration of the RTP:

The local community would have more involvement in the police in the next ten years but not now. We are not convinced that local communities have sufficient abilities to do that yet. During this period, the state needs to educate more local people. In other words, education of the public must cover every area of the country, even in remote areas...

(Assistant Secretary of PRC)

Others also felt that if the public's representatives became involved in appointments and nominations it would cause many problems. Officers would turn to board members to lobby for promotions and promotions instead of approaching senior police administrators. A Station Chief said:

I completely disagree with the public becoming involved in police transfer and nominations because local people have different backgrounds. They are not familiar with policing in the way senior officers are. If the public do, it will definitely lead to many problems. The police will be condemned regarding their activities and operations. We have to realize that officers have both weapons and laws in their hands and they also have the power of arrest. The police may lack all independence and just become the tool of influential local persons who are board members once they can influence decisions about appointments directly.

(Chief of small station, Upper North) 
The Chief was not prepared to discuss how RTP personnel management operated currently but implicit in his concerns was experience with the longestablished system of patronage and the administrative culture which underlay the process of appointments and movements among bureaucrats and the armed forces generally.

In answer to the first of the two questions about police transparency, 'Should the public be engaged in inspecting the police's activities?' a senior NCO who was near retirement said:

The public do not really understand about scrutiny...Nobody loves the police in the way the police do. If the public were able to scrutinize policing, they would want to kill the police. Sometimes, even the police do not like the police.

(Senior Sergeant Major, Investigation, smallstation, Upper South)

His was a frank admission of closed institutional culture, lack of accountability and dubious practice. Another NCO with twenty years' experience who worked in the same station elaborated:

The public should not inspect policing. We sometimes do not want to do things but we have no choice. If I do not conform as my colleagues expect, I am not able to spend my life in this police society. Actually, I do not want to behave badly. Civilians should not interfere. The public is the problem. They do not understand us.

(Senior Sergeant Major, interrogation, small station, Upper South)

An NCO from a small police station in the North explained about provincial culture and the context to policing locally:

How are we ensured the police will not be bullied by external inspectors? When Thais have power, they behave badly. I absolutely disagree with civilian involvement...I have experience of working in both Bangkok and rural areas. In rural areas, it is an influence-based system. Even the drivers of influential people are powerful although they graduated with a primary school education only. When I have to arrest one of those drivers, they tell me, you do not know who we are. In Bangkok, I do not care who you are because I can go back home when I finish working.

(Sergeant Major, Suppression, small station, Upper North)

In answer to the second of the interview questions about police transparency, 'Should there be an Ombudsman's Office specifically for police activities?' the initial reaction was it would lead to more problems than at present:

I think that would put a good front on police inspection. In reality, inspectors would come for money. What's the problem? Take us out for fancy meals in five-star restaurants and explain. How much money did you get this month? Distribute some money to us too. They would not come to help the local police. The more inspections you had, the more money you would have to pay. And when it was near to the round of police movements, then we would have to pay again if there was more inspection. We wouldn't be able to focus on police work at all. The Police Chief at [tourist location withheld], for example, that position costs 7 or 8 million baht or more [US $\$ 220,000-$ US $\$ 250,000]$.

(Senior Sergeant Major, section and location withheld)

Some NCOs supported the idea of an Ombudsman's Office but those in favour saw it as a means of supporting police officers when complaints were made against them:

At present, offenders often complain about the police who arrest them. Those offenders receive consultations from lawyers. If a Police Ombudsman's Office is launched, it would help good police officers to explain to the public or senior police managers what the facts are. It happens that the public do not believe in what the police say...

Nobody knows how bad it is we have it. I have been complained about without 
foundation. The internal complaints process takes a long time, perhaps a year or more. During the process of investigation, I felt disappointed and frustrated with my job because my salary was withheld. An external inspector would make this a quicker procedure and also transparent for the public.

(Corporal, Traffic, small police station, Bangkok)

Others were sure that NCOs would become scapegoats for their bosses' activities if police administration was opened to public scrutiny.

The PRC had not in fact proposed an Ombudsman's Office for the Police in the first place because they saw it as having the same poor reputation with the public for protracted and ineffectual handing of complaints as the Parliamentary Ombudsman's Office for the Civil Service, which currently included the RTP. The PRC had wanted an ICC to establish accountability. The recommendation was not part of the final Police Reform Bill which was submitted to the National Legislative Assembly. As the PRC's Chair described events:

'At the Council of State, the bills - debated and defended by the Police Reform Committee - were subjected to severe editing. To my surprise and chagrin, many parts of the drafts were changed, some by Council members themselves. As a result, the edited drafts strayed from the original drafts that had been submitted and approved in principle by the Cabinet. Subsequently, the Police Reform Bill was completed - with the changes. Contrary to our proposal, the bill on the Independent Committee for Complaints against the Police was doomed. The suggested committee was placed instead as an internal body within the NPA [National Police Authority], with police officers serving as the secretariat.'

(PRC 2009:iv)

The PRC's Chair the interview in English with the observation, 'One cannot avoid politics when considering police reform,' and he elaborated in the preface to the much delayed English-language version of the PRC's final report:
'The abortive police reform reflects Thailand's bureaucratic quagmire caused by chronic political under-development. Although earlier governments have claimed that they recognized the necessity of re-structuring and decentralizing the police organization, nothing has been done accordingly. On the contrary, every government tried its best to ensure its firm political control of the police. Interference in police personnel management, especially regarding appointments, promotions and transfers, has been rampant... Nepotism reigns and abounds. Without constructive reform, the police cannot be expected to carry out their mission effectively. The public will continue to suffer.'

(PRC 2009:v—vi)

\section{CONCLUSION}

The findings from the study explain Retired Police General Vasit's final conclusion about political interference and the barriers to police reform in Thailand and about the drivers behind the way that the RTP has operated in practice, and how it fails to serve the public, based on the opinions and accounts of the RTP's own officers. Our findings about police culture and the intersection between policing and politics provide a detailed case study of the troubled relationship between corruption and democracy in Thailand (Phongpaichit and Piriyarangsan 1996). However, the paradox of the PRC's reform strategy to remove political interference from the administration of the RTP was that its recommendations could also be read as politically motivated. That is, the PRC had been established to quasha resurgent and powerful RTP in the struggle between Thaksin and his political opponents (Connors 2008). Retired Police General Vasit was not independent even if the PRC's report was well-informed and its recommendations wellfounded, coherent and necessary in any move towards more open and accountable policing in the Thai context.

Bayley (2006:11) has remarked that, in general, 'very little attention has been given to the process ... of achieving police reform of a democratic character' in troubled contexts in the developing world and the 'institutional gap' for Thai police reform was as Vasit described it himself, 'chronic political under- 
development'. Davis, Henderson and Merrick (2003: 285) found that moving towards Western models of community-oriented policing, as Vasit had hoped, was crucially dependent on 'local context and history' while Pino and Wiatrowski (2006:8) claimed that no 'onesize-fits-all' in moves away from authoritarian policing in quasi-military contexts, as in Vasit's failed attempts to prepare the ground for 'democratic' policing in the Thai context. Bayley and Perito (2011:6) note that, 'Even though forms of police corruption can be reduced to a generic few, it does not follow that generic solutions will work the same everywhere.' Vasit's attempts to apply standard prescriptions against police corruption -establishing permanent external oversight and making senior managers accountable - were blocked as the RTP's administration continued to be abused to consolidate political power post-2006. O'Neill, Marks and Singh (2007:2) conclude that much more comparative work is necessary and 'much insight can be gained into policing culture by looking beyond the typical Anglo-American perspective.' According to our own study, political self-interest, especially interference in personnel management within the RTP's annual round of appointments, nominations, transfers and promotions, allied to nepotism and position buying for anticipated rewards, represented the key drivers of police culture and also the key barriers to police reform in the Thai context.

\section{ACKNOWLEDGEMENTS}

The authors wish to thank the Royal Thai Police who supported Pol. Lt. Col. Poothakool's research leave and permitted access for the study and the officers who participated. The authors also wish to thank Prof. Duncan McCargo, Leeds University, UK, and anonymous reviewers for their critical comments.

\section{REFERENCES}

Baker, Chris and Pasuk Phongpaichit. 2009. A History of Thailand, Second edition. Cambridge: Cambridge University Press. http://dx.doi.org/10.1017/CBO9781139194877

Bayley, David H.2006.Changing the Guard: Developing Democratic Police Aboard. Oxford: Oxford University Press.

Bayley, David H and Robert Perito. 2011. 'Police Corruption: What Past Scandals Teach Us About Current Challenges.' Washington DC: Institute of Peace. Available at: http://www.usip.org/files/resources/SR\%20294.pdf (accessed March23 2012).

Brewer, John D. 1993.'Sensitivity as a Problem in Field Research: a Study of Routine Policing in Northern Ireland.' Pp. 125-46 in Researching Sensitive Topics edited by C.M Renzetti and R.M. Lee. London, Sage.

Brewer, John D. and Albert Hunter.2006.Foundations of Multimethod Research: Synthesizing Styles. London, Sage.
Callahan, William A. 2005. 'The Discourse of Vote Buying and Political Reform in Thailand.' Pacific Affairs 78(1): 95-113. http://dx.doi.org/10.5509/200578195

Chaloemtiarana, Thak. 2007.Thailand: The Politics of Despotic Paternalism, Second edition. Ithaca, NY: Southeast Asia Program, Cornell University.

Connors, Michael K.1999, 'Political Reform and the State in Thailand.' Journal of Contemporary Asia 29(4): 202-26.Republished in Politics of Modern Southeast Asia edited byA. Hicken. London, Routledge. http://dx.doi.org/10.1080/00472339980000321

Connors, Michael K. 2008. 'Article of Faith: the Failure of Royal Liberalism in Thailand.' Journal of Contemporary Asia 38(1): 143-65. http://dx.doi.org/10.1080/00472330701652000

Connors, Michael K. and Kevin Hewison.2008. 'Thailand's "Good Coup": the Fall of Thaksin, the Military and Democracy.' Journal of Contemporary Asia 38(1): 1-10. http://dx.doi.org/10.1080/00472330701651929

Dejkunjorn, Vasit. 1987. Savage Inspector [Salawateurn]. Bangkok, Matichon.

Dejkunjorn, Vasit. 1994. Chief Inspector [Salawatyai]. Bangkok, Matichon.

Dejkunjorn, Vasit. 1996. Special Branch [Santibarn]. Bangkok, Matichon.

Davis, Robert C., Nicole J. Henderson and Cybele Merrick 2003.'Community Policing: Variations on the Western Model in the Developing World.' Police Practice and Research 4(3):285-300. http://dx.doi.org/10.1080/1561426032000113870

Fineman, Daniel. 1997. A Special Relationship: The United States and Military Government in Thailand, 1947 to 1958 .Honolulu, $\mathrm{HI}$ : University of Hawaii Press.

Kittiyaluck, Kittipong. 2007. Police Reform: Please Listen Again. Bangkok, Matichon.

Laothamas, Anek. 1992.Business Associations and the New Political Economy of Thailand: From Bureaucratic Polity to Liberal Corporatism. Boulder, CO: Westview Press.

McCargo, Duncan. 2000. Politics and the Press in Thailand: Media Machinations. London: Routledge.

McCargo, Duncan. 2004. 'Buddhism, Democracy and Identity in Thailand. 'Democratization 11(4):155-70. http://dx.doi.org/10.1080/1351034042000234576

McCargo, Duncan. 2005.'Network Monarchy and Legitimacy Crises in Thailand.' The Pacific Review18(4):499-519. http://dx.doi.org/10.1080/09512740500338937

McCargo, Duncan. 2006. 'Rethinking Thailand's Southern Violence. 'Critical Asian Studies 38(1):3-10. http://dx.doi.org/10.1080/14672710600556395

McCargo, Duncan and Ukrist. Pathmanand. 2005. The Thaksinization of Thailand: Thaksin's Political Discourse. Copenhagen, Denmark: Nordic Institute of Asian Studies Press.

McVey, Ruth. 2000. Money and Power in Provincial Thailand Honolulu, HI: University of Hawaii Press.

Ockey, James. 1998. 'Crime, Society and Politics in Thailand.' Pp. 39-53 in Gangsters, Democracy and the State in Southeast Asia edited by C. A. Trocki. New York, NY: Southeast Asia Program Cornell University.

O'Neill, Megan, Monique Marks and Anne-Marie Singh. 2007. Police Occupational Culture: New Debates and Directions. Oxford: Elsevier Press.

Phongpaichit, Pasukand Chris Baker. 2004. Thaksin: the Business of Politics in Thailand. Chiang Mai, Thailand: Silkworm Books.

Phongpaichit, Pasuk and Sungsidh Piriyarangsan. 1996. Corruption and Democracy in Thailand, Second edition. Chiang Mai, Thailand, Silkworm Books. 
Pino, Nathanand Michael D. Wiatrowski. 2006. Democratic Policing in Transitional and Developing Countries, Burlington, VT: Ashgate.

PRC, Police Reform Committee. 2009. Police Reform in Thailand. Nonthaburi, Bangkok: Ministry of Home Affairs.

Roberts, Simon and Claire Provost. 2011. 'Corruption Index 2011 from Transparency International: Find Out How Countries Compare.' Available at: http://www.guardian.co.uk/news/ datablog/2011/dec/01/corruption-index-2011-transparencyinternational(accessed June4 2012).

Skolnick, Jerome H. and David. H. Bayley. 1988. Themes and Variations in Community Policing. Chicago, IL: University of Chicago Press.
Suriyasarn, Busakorn and Christopher G. Moore. 2006. In His Majesty's Footsteps: a Personal Memoir by Vasit Dejkunjorn. Bangkok: Heaven Lake Press

Tamada, Yoshifumi. 1991. 'Itthiphon and Amnat: an Informal Aspect of Thai Politics.' Southeast Asian Studies28(4): 455-66.

World Bank. 2011. Available at http://siteresources.worldbank.org/ DATASTATISTICS/Resources/GNIPC.pdf (accessed May6 2012).

World Bank. 2012. Available at: http://www.worldbank.org/en/ country/thailand (accessed May6 2012).

WVS-Thailand. 2007.'World Values Survey Official Data File v.20090901.' World Values Survey Association, www.worldvaluessurvey.org

Received on 29-07-2013

Accepted on 06-09-2013

Published on 10-09-2013

DOI: http://dx.doi.org/10.6000/1929-4409.2013.02.35

(c) 2013 Poothakool and Glendinning; Licensee Lifescience Global.

This is an open access article licensed under the terms of the Creative Commons Attribution Non-Commercial License (http://creativecommons.org/licenses/by-nc/3.0/) which permits unrestricted, non-commercial use, distribution and reproduction in any medium, provided the work is properly cited. 